UDC 159.9

DOI: $10.23951 / 2782-2575-2021-2-68-75$

\title{
PSYCHOLOGY OF ADOLESCENTS WITH INTELLECTUAL DISABILITY COMPLICATED BY VISUAL IMPAIRMENT: FEATURES OF INTERPERSONAL RELATIONS
}

\author{
E.V. Grebennikova, I.L. Shelekhov, E.A. Filimonova \\ Tomsk State Pedagogical University, Tomsk, Russian Federation
}

It is customary to consider interpersonal relationships as a significant factor influencing the development of individual mental processes and personality. In recent years, studies that reveal the specifics of interpersonal relationships in persons with different types of dysontogenesis, including those with intellectual disabilities, have been of particular interest to specialists. This article presents the results of studying the interpersonal relationships of adolescents with intellectual disabilities (ID), complicated by visual impairment. When it comes to comparing the interpersonal relations in adolescents with intellectual disabilities, complicated by visual impairment and their peers with uncomplicated intellectual disabilities, the results of the study show that there are features which are general to both groups and features which are specific to only one group. In the surveyed groups, only one-third of adolescents consider their mother and father as a parental couple. More often than not, they communicate with their mother and refuse to communicate with their father. The adolescents of both groups are characterized by the following: low involvement in terms of interaction with peers; the presence of emotionally deficient or emotionally excessive reactions (with a predominance of the emotionally deficient type); poor decision-making, the desire to shift responsibility to others; lack of interest to become a leader; frequent conflicts with peers and inability to resolve them constructively. In addition, adolescents in the surveyed groups often demonstrate reactions to frustration in an active-aggressive or a passive-suffering manner. Moreover, in adolescents with uncomplicated ID, reactions of an active-aggressive type dominate, and in adolescents with ID complicated by visual impairment, reactions of a passive-suffering type are dominant. It is important to note that adolescents with ID complicated by visual impairment tend to be isolated from their peers and show high affection for home and their families.

Keywords: interpersonal relations, adolescent, intellect, intellectual disabilities, intellectual disabilities, visual impairment.

Currently, a relatively large number of studies have been carried out in psychology on various aspects of interpersonal relations, in particular:

- B.G. Ananiev [1] and V.N. Myasishchev [2], speaking about the nature of interpersonal interaction, singled out three components: cognition of each other, emotional response, and interpersonal communication reactions;

- L. Anert [3], A.P. Okoneshnikova [4], E.N. Reznikov [5], S.D. Gurieva [6], studying interpersonal relations at the interethnic level, noted the influence of interethnic differences on the nature of interpersonal relations;

-A.A. Rean [7], J.L. Kolominsky [8], I.S. Kon [9], A.V. Mudrik [10], N.N. Obozov [11] emphasized the role and place of interpersonal relations in the educational space;

* Original Russian language version of the article: Grebennikova E.V., Shelekhov I.L., Filimonova E.A. Mezhlichnostnyye otnosheniya podrostkov s umstvennoy otstalost'yu, oslozhnyonnoy narusheniyem zreniya [Interpersonal Relations of Adolescents with Mental Retardation, Complicated by Visual Impairment]. Nauchno-pedagogicheskoye obozreniye - Pedagogical Review, 2020, vol. 1 (29), pp. 54-63 (in Russian). DOI 10.23951/2307-6127-2020-1-54-63 
- T.E. Argentova [12], G.A. Berulava [13], E.A. Klimov [14], V.N. Kunitsyna [15], V.V. Latynov [16], V.S. Merlin [17] investigated the style features of interpersonal interaction;

- V.P. Levkovich [18], V.A. Smekhov [19], A.R. Shavaleeva [20], E.G. Eidemiller, and V.V. Yustitskis [21] analyzed interpersonal family relations;

- I.A. Dzhidaryan [22], K. Izard [23], V.A. Labunskaya [24], Yu.A. Mendzheritskaya [25], A.I. Krupnoe, and colleagues [26] studied the influence of feelings and emotions on the nature of relationships between people.

There are many studies concerning the interpersonal relations of children and adolescents with dysontogenetic development, including intellectual disabilities [27-29]. It is known that with ID, there are: delay and instability in the development of interpersonal relations; difficulty in the development of communicative ties; a large number of small micro-groups; frequent change of unofficial leaders, while leaders are often singled out on a random basis; a large number of children in extreme status categories, especially in the "isolated" category; instability in the manifestation of empathy and sympathy; fragmentation of social experience [30-33]. However, it should be noted that there are quite a few studies in which the specificity of interpersonal relations of adolescents with ID complicated by impaired functions of analyzers was studied, although the number of such children among students of special schools is increasing every year. Of course, studies aimed at studying interpersonal relationships in this category of adolescents are essential for organizing effective interaction between participants in the educational process.

The relevance and practical significance of the above issue determined the choice of our study - interpersonal relations of adolescents with intellectual disabilities complicated by visual impairment.

Organization of empirical research. The study was conducted over six years (2014-2019) on the basis of three educational institutions in Tomsk for students with intellectual disabilities. The study involved 60 adolescents with mild ID 13-16 years old, who were divided into two groups of equal size: 1) adolescents with uncomplicated ID;2) adolescents with ID complicated by visual impairment (amblyopia, astigmatism, myopia).

To study the interpersonal relations of adolescents, the questionnaire "My environment" was used; R. Gilles' method "Film-test," adapted by I.N. Gilyasheva and N.D. Ignatieva; questionnaire of interpersonal relations (QIR) by V. Schutz method, "Assessment of relationship with the class."

Before the study began, parents provided permission for their children to participate in the research.

Empirical research results and the discussion. All adolescents participating in the survey willingly agreed to answer the questionnaire. During the survey, the students behaved appropriately. In case of any questions, the student could receive a comment from the psychologist.

From the answers to the question: "With whom do you live?" we found out that most of the adolescents of the $1^{\text {st }}(80 \%)$ and the $2^{\text {nd }}(60 \%)$ groups live in complete families. The upbringing of adolescents from single-parent families was carried out primarily by mothers, often with the help of grandparents.

To the question: "Do you like spending time at home? Would you like to go home from school as soon as possible?" $60 \%$ of adolescents in the $1^{\text {st }}$ group answered yes, $33 \%$ of adolescents said they did not want to go home if there was a conflict situation in the family, and only $7 \%$ of adolescents did not want to return home from school. A different situation was noted in the $2^{\text {nd }}$ group of adolescents. In this group, adolescents were divided into two categories: in the first category, $73 \%$ of adolescents wanted to return home after school as soon as possible; in the second category, $27 \%$ of adolescents only sometimes did not want to go home. 
The adolescents of the $1^{\text {st }}$ and $2^{\text {nd }}$ groups, living in a boarding school, noted a reluctance to return home. Amongst the reasons for their unwillingness to return home, this category of adolescents named poor living conditions, lack of attention from family members, and frequent conflicts.

To the question: "Do your parents often talk to you about your affairs?" the answers of adolescents in the 2 groups were distributed in the same way: 20\% of adolescents answered positively, $60 \%$ of adolescents noted that parents are rarely interested in their affairs, $20 \%$ of adolescents indicated that parents are indifferent to their activities. Most of the adolescents who noted their parents' indifference to their activities lived in a boarding school.

To the question: "Do you feel comfortable at home? Are you scared to be at home?" more than half of the adolescents in the $1^{\text {st }}(60 \%)$ and $2^{\text {nd }}(67 \%)$ groups answered that they were quite comfortable at home.

To the question: "Do your parents often play or go out for a walk with you? Do they read books to you?" $80 \%$ of adolescents in the two surveyed groups answered that their parents rarely interact with them. In this case, the initiator of communication is often the adolescent. Unfortunately, $20 \%$ of adolescents noted a lack of interaction with their parents.

From the answers to the following questions: "If someone offended you or were you just upset, would you immediately tell your mom, dad, or friend about it? would you tell anyone?" it can be seen that from the $1^{\text {st }}$ group, $47 \%$ of adolescents would not tell anyone, $33 \%$ - to their mothers, $20 \%$ - to a friend. In group $2.47 \%$ of adolescents would tell their mothers, $33 \%$ of adolescents would not tell anyone, and $20 \%$ of adolescents would tell a friend about their problem. It is important to note that adolescents of the $1^{\text {st }}$ and $2^{\text {nd }}$ groups living in a boarding school prefer not to tell anyone about their problems.

To the question: "If you have something to say but find it difficult to express, what will your parents do?" $40 \%$ of the adolescents of the $1^{\text {st }}$ group and $33 \%$ of the $2^{\text {nd }}$ group answered that parents would patiently listen to them and help with an issue. More than half of the adolescents in the $1^{\text {st }}(60 \%)$ and $2^{\text {nd }}(67 \%)$ groups reported that they would not be listened to and sent to another parent in this situation. The results obtained reflect the level of intolerance of parents towards their children, which, of course, hurts parent-child relationships.

To the question: "Do you have many friends?" adolescents of the $1^{\text {st }}$ group answered as follows: more than three friends $-27 \%$, only one friend $-53 \%$, I have no friends $-20 \%$. In group $2.13 \%$ mentioned more than three friends, $60 \%$ mentioned one friend, and $27 \%$ believe they have no friends. The answers show that $20-27 \%$ of adolescents surveyed do not have friends, negatively affecting their socio-psychological development.

To the question: "Would you entrust your secret to a friend and turn to him for help in a difficult situation?" only $20 \%$ in groups 1 and 2 answered yes.

To the question: "Why do you love friends?" in the two groups, the most common answers were: he is good, kind, cheerful.

To the question: "Do you often have conflicts with your friends?" more than half of the adolescents in the $1^{\text {st }}(80 \%)$ and $2^{\text {nd }}(67 \%)$ groups answered positively. Moreover, in most cases, conflicts were resolved with the help of an educator or teacher. In a situation where teenagers are trying to get out of a conflict situation on their own, they use non-constructive coping strategies.

Based on the results of the survey, we can say that adolescents in the two groups: 1) have parents who devote little time to them and are often indifferent to their problems; 2) build a more trusting relationship with their mothers; 3) experience difficulties in communicating with peers and, in the event of conflict situations, are not able to constructively resolve them. 
At the same time, the survey showed that adolescents in the $2^{\text {nd }}$ group demonstrate greater attachment to home and their family, while adolescents in the $1^{\text {st }}$ group have a greater number of friends.

Using the methodology of R. Gilles, it was revealed that $60 \%$ of adolescents in the $1^{\text {st }}$ group had a high indicator on the Conflict/Aggressiveness scale, and $40 \%$ of adolescents had a low one. In group 2, the opposite situation was observed $-40 \%$ of adolescents had a high indicator on this scale, and $60 \%$ of adolescents had a low one.

On the scale "Reaction to frustration" in the $1^{\text {st }}$ group, the dominant reactions were of the active-aggressive type (53\%): shouting, ridicule, protest, going against the rules, anger, fights. In group 2, passive-suffering reactions were more often recorded $(60 \%)$ : crying, resentment, complaints. Interestingly, neutral reactions were characteristic of the same number of adolescents from the two surveyed groups (13\%).

According to the scale "Striving for solitude, isolation" among adolescents of the $1^{\text {st }}$ group, no tendency to isolate themselves from their peers was revealed. In contrast, in the $2^{\text {nd }}$ group, such a tendency was found in $20 \%$ of adolescents. It is important to note that adolescents of both the $1^{\text {st }}$ and $2^{\text {nd }}$ groups have a weak involvement in interaction with their peers, as evidenced by low indicators on the scale "The desire to communicate in large groups of children." In addition, the majority of adolescents in the surveyed groups (80\%) do not tend to dominate ("Domination" scale).

The results of the study, obtained on the scales "Attitude to mother," "Attitude to father," "Attitude to mother and father as a parental couple," allowed us to determine the nature of relations in the family. In $40 \%$ of adolescents from group 1 and $53 \%$ of adolescents from group 2 , low interaction with their father and stronger interaction with their mother was noted (adolescents with fathers who did not participate in their upbringing did not note the importance of relationships with parents on the given scale). Among adolescents of the $1^{\text {st }}$ and $2^{\text {nd }}$ groups living in a boarding school, the desire to communicate with their mother is more pronounced than that of their peers living in a family.

According to the scale "Attitude to mother and father as to a parental couple," there is no difference in the average indicators in both groups. It was revealed that only $33 \%$ of adolescents perceive their mother and father as a parental couple. The results obtained reflect an objective family situation: adolescents who are brought up in complete and prosperous families, as a rule, perceive their father and mother as a parental couple, and adolescents whose parents do not live together or are in conflict relationships do not characterize them as a couple.

Based on the results obtained on the scales "Attitude towards grandmother, grandfather and other relatives," "Attitude towards siblings," we can note a good attitude of the majority of adolescents in the two surveyed groups towards their grandparents and siblings. However, some adolescents showed a neutral attitude towards this category of relatives. In cases where grandparents mainly carried out the upbringing of adolescents, they express high importance towards their relations with them.

The need to interact with peers is expressed in $27 \%$ of adolescents from group 1 and $24 \%$ from group 2. It is noteworthy that the relationship with their teachers is significant for $33 \%$ of adolescents in the $1^{\text {st }}$ group and $40 \%$ of adolescents in the $2^{\text {nd }}$ group.

The results obtained by the R. Gilles method allow us to draw the following conclusions:

1. In groups 1 and 2, a relatively large percentage of adolescents have a low rate of interaction with their father against the background of their mother's preference. In addition, only a third of adolescents in each group consider their father and mother as a parental couple. 
2. The majority of adolescents in the surveyed groups are weakly involved in interaction with peers and do not tend to dominate.

3. The adolescents of the surveyed groups more often demonstrate active-aggressive or passive-suffering reactions. Moreover, active-aggressive reactions dominate among adolescents of the $1^{\text {st }}$ group, and among adolescents of the $2^{\text {nd }}$ group, passive-suffering reactions dominate.

Using the questionnaire by V. Schutz in adolescents from the surveyed groups, the features of interpersonal behavior were determined based on three needs - inclusion, control, emotion.

Concerning the inclusion in adolescents of the $1^{\text {st }}$ and $2^{\text {nd }}$ groups, four types of behavior were identified. Socially poor behavior was observed in $40 \%$ of adolescents in the $1^{\text {st }}$ group and $50 \%$ in the $2^{\text {nd }}$ group. Socially excessive and socially balanced behavior was found in equal percentages $27 \%$ each in the $1^{\text {st }}$ and $20 \%$ in the $2^{\text {nd }}$ group. The pathological type of interpersonal relations in the $1^{\text {st }}$ group was $6 \%$, and the $2^{\text {nd }}$ group was $10 \%$. Thus, most of the adolescents surveyed are characterized by socially undesirable behavior. There is a predominance of the socially deficient type of interpersonal behavior, in which adolescents have a low level of interaction, lack of communication, and avoidance of large peer groups.

Concerning the control among adolescents of the $1^{\text {st }}$ and $2^{\text {nd }}$ groups, four types of interpersonal relations are distinguished. The distribution of the types of interpersonal relations in the area of control was as follows: "abdicates" $-40 \%$ from the $1^{\text {st }}$ group and $50 \%$ from the $2^{\text {nd }}$ group, "autocrats" and "democrats" $-27 \%$ from the $1^{\text {st }}$ group, and $20 \%$ of adolescents from the $2^{\text {nd }}$ group, "pathology" $-6 \%$ from the $1^{\text {st }}$ group and $10 \%$ from the $2^{\text {nd }}$ group. The presented results show that "abdicates" adolescents are most common in the surveyed groups, which are characterized by obedience, indecision in decision-making, and the desire to shift responsibility onto others.

Concerning emotions, both in the $1^{\text {st }}$ and the $2^{\text {nd }}$ groups, three types of interpersonal relations were identified: "emotionally deficient," "emotionally excessive," "emotionally balanced." At the same time, among the adolescents of the surveyed groups, the "emotionally deficient" type was more common ( $40 \%$ in the $1^{\text {st }}$ group and $50 \%$ in the $2^{\text {nd }}$ group), in which adolescents have a weak feeling of emotional attachment and tend to avoid close personal relationships with others. It is important to note that a fairly large percentage of adolescents $(33 \%)$ of the $1^{\text {st }}$ and $2^{\text {nd }}$ groups had an "emotionally excessive" type of relationship.

The presented results indicate that more than half of the surveyed adolescents in the "emotions" category have socially inadequate types of interpersonal relationships - "emotionally deficient" or "emotionally excessive."

Using the methodology "Assessment of the relationship of a teenager with the class," we found that adolescents in the studied groups most often have an individualistic type of perception: in group 1 - in $47 \%$ of adolescents, in group 2 - in $60 \%$ of adolescents. Adolescents of this type perceive the group as a hindrance to their activities or are neutral towards it. The group is of no value to the personality of the adolescent. The teenager shies away from joint forms of activity, preferring individual work, and is limited in contacts.

In addition to the individualistic perception, adolescents of the two groups also have a pragmatic perception. This type of perception is typical for $33 \%$ of adolescents in the $1^{\text {st }}$ group and $20 \%$ in the $2^{\text {nd }}$ group. Teenagers of this type perceive the group as a means of contributing to achieving specific individual goals. In this case, the group is perceived and evaluated from its "usefulness" for the adolescents themselves. Preference is given to more competent team members who can assist, take on a complex problem, or serve as a source of the necessary information. 
Only $20 \%$ of adolescents from the surveyed groups perceive the group as an independent value. For them, the problems of the group and its members come to the fore. There is interest in the success of each group member and the group as a whole, the desire to contribute to group activities to help classmates in need. There is a need for collective forms of work. This type of perception is called "collectivist."

Thus, in most adolescents in the surveyed groups, there is a focus on themselves and a preference for an individualistic type of group perception. The group does not represent an independent value for the personality of an adolescent.

Summarizing the results of the empirical study, we can say that the interpersonal relationships of adolescents with intellectual disabilities, complicated by visual impairment, in many respects repeat those of adolescents with an uncomplicated form of intellectual disabilities. However, specific features must be taken into account when planning correctional and developmental work on the formation of optimal interpersonal relationships.

\section{References}

1. Anan'yev B.G. Chelovek kak predmet poznaniya [Man as a subject of knowledge]. St. Petersburg, Piter Publ., 2001. 288 p. (in Russian).

2. Myasishchev V.N. Psikhologiya otnosheniy [Psychology of relations]. Ed. A.A. Bodalev. Moscow, MPSI Publ., 2003. 104 p. (in Russian).

3. Anert L., Mayshner T., Shmidt A., Doskin V.A. Kross-kul'turnoye issledovaniye vzaimodeystviya s det'mi russkikh i nemetskikh materey [Cross-cultural study of interaction with children of Russian and German mothers]. Voprosy psikhologii, 1994, no. 5, pp. 20-30 (in Russian).

4. Okoneshnikova A.P. Mezhetnicheskoye vospriyatiye i ponimaniye lyud'mi drug druga [Interethnic perception and understanding by people of each other]. Perm', Zvezda Publ., 1999. 406 p. (in Russian).

5. Reznikov Ye.N. Psikhologiya etnicheskogo obshcheniya [Psychology of ethnic communication]. Moscow, Institute of Psychology RAS Publ., 2007. 160 p. (in Russian).

6. Guriyeva S.D. Metodologicheskiye $i$ teoreticheskiye aspekty izucheniya mezhetnicheskikh otnosheniy [Methodological and theoretical aspects of the study of interethnic relations]. Saint Petersburg, St. Petersburg State University Publ., 2010. 180 p. (in Russian).

7. Rean A.A., Kolominskiy Ya.L. Sotsial'naya pedagogicheskaya psikhologiya [Social pedagogical psychology]. Saint Petersburg, Piter Publ., 2000. 416 p. (in Russian).

8. Kolominskiy Ya.L. Psikhologiya detskogo kollektiva: sistema lichnykh vzaimootnosheniy [Psychology of the children's team: system of personal relationships]. Minsk, Narodnaya asveta Publ., 1984. 239 p. (in Russian).

9. Kon I.S. Psikhologiya starsheklassnika: posobiye dlya uchiteley [Psychology of a high school student: a manual for teachers]. Moscow, Prosvyashcheniye Publ., 1980. 191 p. (in Russian).

10. Mudrik A.V. Obshcheniye kak faktor vospitaniya shkol'nikov [Communication as a factor in the education of schoolchildren]. Moscow, Pedagogika Publ., 1984. 112 p. (in Russian).

11. Obozov V.V. Dinamika mezhlichnostnykh otnosheniy studentov i yeye svyaz's ekstraversiyey i neyrotizmom [Dynamics of interpersonal relations of students and its relationship with extraversion and neuroticism]. Chelovek i obshchestvo, 1973, no. 13, pp. 149-154 (in Russian).

12. Argentova T.Ye. Stil' obshcheniya kak faktor effektivnosti sovmestnoy deyatel'nosti [Communication style as a factor in the effectiveness of joint activities]. Psikhologicheskiy zhurnal-Psychological Journal, 1984, no. 6, pp. 130-133 (in Russian).

13. Berulava G.A. Stil' individual'nosti: teoriya i praktika: uchebnoye posobiye [Style of individuality: theory and practice: a training manual]. Moscow, Pedagogicheskoye obshchestvo Rossii Publ., 2001. 236 p. (in Russian).

14. Klimov Ye.A. Individual'nyy stil' deyatel'nosti v zavisimosti ot tipologicheskikh svoystv nervnoy sistemy [Individual style of activity depending on the typological properties of the nervous system]. Kazan', KSU Publ., 1969. 278 p. (in Russian).

15. Kunitsyna V.N. Stil' obshcheniya i yego formirovaniye [Communication style and its formation]. Leningrad, Znaniye Publ., 1985. 20 p. (in Russian). 
16. Latynov V.V. Stili rechevogo kommunikativnogo povedeniya: struktury i determinanty [Styles of speech communicative behavior: structures and determinants]. Psikhologicheskiy zhurnal-Psychological Journal, 1995, no. 6, pp. 90-100 (in Russian).

17. Merlin V.S. Individual'nyy stil' obshcheniya [Individual communication style]. Psikhologicheskiy zhurnal Psychological Journal, 1982, no. 4, pp. 26-36 (in Russian).

18. Levkovich V.P. Osobennosti supruzheskikh vzaimootnosheniy v raznonatsional'nykh sem'yakh [Features of marital relationships in multinational families]. Psikhologicheskiy zhurnal-Psychological Journal, 1990, no. 1, pp. 25-36 (in Russian).

19. Smekhov V.A. Opyt psikhologicheskoy diagnostiki i korrektsii konfliktnogo obshcheniya v sem'ye [Experience in psychological diagnosis and correction of conflict communication in the family]. Voprosy psikhologii, 1985, no. 4, pp. 83-92 (in Russian).

20. Shavaleyeva A.R., Aydarov V. Osobennosti obshcheniya i mezhlichnostnykh otnosheniy suprugov v sovremennoy molodoy sem'ye [Features of communication and interpersonal relations of the married couples are in modern young family]. Nauchnoye obozreniye. Pedagogicheskiye nauki - Science Review. Pedagogical Sciences, 2017, no. 6-1, pp. 143-145 (in Russian).

21. Eydemiller E.G., Yustitskis V.V. Psikhologiya i psikhoterapiya sem'i [Psychology and psychotherapy of the family]. Saint Petersburg, Piter Publ., 1999. 656 p. (in Russian).

22. Dzhidar'yan I.A. Psikhologiya schast'ya i optimizma [Psychology of happiness and optimism]. Moscow, Institute of Psychology of the Russian Academy of Sciences Publ., 2013. 268 p. (in Russian).

23. Izard K. Psikhologiya emotsiy [Psychology of emotions]. Saint Petersburg, Piter Publ., 2000. 460 p. (in Russian).

24. Labunskaya V.A., Mendzheritskaya Yu.A., Breus Ye.D. Psikhologiya zatrudnennogo obshcheniya: Teoriya. Metody. Diagnostika. Korrektsiya [Psychology of difficulty communication: Theory. Methods Diagnostics. Correction]. Moscow, Akademiya Publ., 2001. 288 p. (in Russian).

25. Mendzheritskaya Yu.A. Osobennosti empatii sub"yektov zatrudnennogo obshcheniya [Features of empathy of subjects of difficult communication]. Prakticheskaya psikhologiya, 1999, no. 4, pp. 54-64 (in Russian).

26. Krupnov A.I., Ol'shannikova A.Ye., Domodedov V.A. Sootnosheniye pokazateley emotsional'nosti i dinamicheskikh kharakteristik obshcheniya [Correlation of indicators of emotionality and dynamic characteristics of communication]. Voprosy psikhofiziologii aktivnosti $i$ samoregulyatsii lichnosti [Questions of the psychophysiology of activity and self-regulation of personality]. Sverdlovsk, 1979. Pp. 17-25 (in Russian).

27. Viytar E.A. Issledovaniye mezhlichnostnykh otnosheniy i interpersonal'noy pertseptsii slaboslyshashchikh shkol'nikov [The study of interpersonal relationships and interpersonal perception of hearing impaired students]. Defektologiya - Defectology, 1981, no. 4, pp. 30-35 (in Russian).

28. Grebennikova E.V., Shelekhov I.L., Lyalina I.I. Mezhlichnostnoye obshcheniye kak marker effektivnoy sotsializatsii podrostkov s zaderzhkoy psikhicheskogo razvitiya [Interpersonal communication as a marker of effective socialization of adolescents with mental retardation]. Nauchno-pedagogicheskoye obozreniye Pedagogical Review, 2016, vol. 1 (11), pp. 26-30 (in Russian).

29. Grebennikova Ye.V., Shelekhov I.L., Shelkunova A.F. Sotsial'no-psikhologicheskiye osobennosti detey starshego doshkol'nogo vozrasta s narusheniyami rechi [Social and psychological characteristics of senior preschoolers with speech disorders]. Nauchno-pedagogicheskoye obozreniye - Pedagogical Review, 2018, vol. 4 (22), pp. 18-26 (in Russian). DOI: 10.23951/2307-6127-2018-4-18-26.

30. Shipitsyna L.M. "Neobuchayemyy" rebenokv sem'ye i obshchestve. Sotsializatsiya detey s narusheniyem intellekta ["Uneducable" child in the family and society. Socialization of children with intellectual disabilities]. Saint Petersburg, Rech' Publ., 2005. 447 p. (in Russian).

31. Gordiyenko Ye.A. Nekotoryye psikhologo-pedagogicheskiye aspekty vzaimootnosheniy umstvenno otstalykh uchashchikhsya $v$ kollektive [Some psychological and pedagogical aspects of the relationship of mentally retarded students in the team]. Defektologiya - Defectology, 1981, no. 5, pp. 14-20 (in Russian).

32. Nikandrova T.S. Mezhlichnostnyye otnosheniya podrostkov s intellektual'noy nedostatochnost'yu i ikh razvitiye [Interpersonal relations of adolescents with intellectual disability and their development]. Deti s problemami v razvitii, 2004, no. 3, pp. 15-17 (in Russian).

33. Pecherskiy V.G., Pecherskiy A.V. Kommunikativnaya aktivnost' podrostkov s intellektual'nym nedorazvitiyem v kontekste problem produktivnogo lichnostnogo vzaimodeystviya [Communicative activity of adolescents with intellectual underdevelopment in the context of problems of productive personal interaction]. Defektologiya Defectology, 2006, no. 3, pp. 46-52 (in Russian). 
Elena V. Grebennikova, Candidate of Biological Sciences, Associate Professor, Associate Professor at the Department of Personality Development Psychology, Faculty of Psychology and Special Education, Tomsk State Pedagogical University (ul. Kievskaya, Tomsk, 60, Russian Federation, 634061).

E-mail: grebennikova971@mail.ru

Igor L. Shelekhov, Candidate of Psychological Sciences, Associate Professor, Corresponding Member of the International Academy of Psychological Sciences, Associate Professor at the Department of Personality Development Psychology at the Faculty of Psychology and Special Education, Tomsk State Pedagogical University (ul. Kievskaya, Tomsk, 60, Russian Federation, 634061).

Email: short@sibmail.com

ORCID iD: 0000-0001-7672-1064

SPIN code: $8638-6249$

Elena A. Filimonova, Senior Lecturer, Department of Defectology, Faculty of Psychology and Special Education, Tomsk State Pedagogical University (ul. Kievskaya, Tomsk, 60, Russian Federation, 634061).

E-mail: filimonova64@list.ru 